\title{
ANALISIS KETERKAITAN SEKTOR PERTANIAN DAN PENGARUHNYA TERHADAP PEREKONOMIAN INDONESIA (ANALISIS INPUT OUPUT)
}

\author{
Retno Febriyastuti Widyawati \\ Alumnus Program Doktor FEB Universitas Gadjah Mada, Indonesia \\ Email: retnofebriyastuti@gmail.com
}

\begin{abstract}
Abstrak: Analisis Keterkaitan Sektor Pertanian dan Pengaruhnya Terhadap Perekonomian di Indonesia (Analisis Input Output). Sektor pertanian masih menjadi andalan penciptaan lapangan pekerjaan dalam jumlah yang cukup besar dibandingkan dengan sektor-sektor lainnya dalam perekonomian di Indonesia. Hal ini menjadikan peluang sektor pertanian dalam pengaruhnya terhadap perekonomian di Indonesia. Artikel ini bertujuan untuk meneliti keterkaitan ke depan dan ke belakang sektor pertanian dengan sektor-sektor lain di Indonesia dan meneliti dampak dari angka pengganda sektor pertanian. Analisis yaitu Input-Output dengan data sekunder InputOutput Indonesia 2010. Hasil menunjukkan bahwa sektor industri pengolahan dan sektor listrik, gas, air bersih memiliki keterkaitan ke depan terhadap sektor pertanian. Selanjutnya, sektor listrik, gas, air bersih; dan sektor bangunan memiliki keterkaitan ke belakang terhadap sektor pertanian. Hasil pengganda output sektor pertanian memiliki dampak pengganda output yang lebih rendah dibandingkan sektor lainnya, sedangkan pengganda pendapatan rumah tangga dan kesempatan kerja memiliki dampak pengganda yang lebih besar dibandingkan sektor lainnya.
\end{abstract}

Kata Kunci: Pertanian, Input-Output, Keterkaitan, Angka Pengganda

\begin{abstract}
Linkage Analysis of Agricultural Sector and Effect on the Economy in Indonesia (Input-Output Analysis). The agricultural sector is still the mainstay of job creation in large enough quantities compared to other sectors of the economy in Indonesia. It makes the chances of the agricultural sector in its influence on the economy in Indonesia. This article aims to examine the relationship forward and backward linkages agricultural sector with other sectors in Indonesia and examines the impact of multiplier output agriculture sector on the economy. Analysis use InputOutput with secondary data Input-Output Indonesia 2010. The results showed that the manufacturing sector and electricity, gas, water sector had been linked to the future of the agricultural sector. Furthermore, electricity, gas, water sector; and the building sector have backward linkages to the agriculture sector. The multiplier output agricultural sector has multiplier output impact lower than other sectors in the economy. Multiplier household income and employment agriculture have a greater multiplier effect than other sectors.
\end{abstract}

Keywords: Agriculture, Input-Output, Linkages, Multiplier Effect

\section{PENDAHULUAN}

Indonesia adalah negara yang memiliki kekayaan atas sumber daya alam yang melimpah. Kekayaan sumber daya tersebut terdiri dari sumber daya air, sumber daya lahan, sumber daya hutan, sumber daya laut, maupun keanekaragaman hayati yang terkandung di dalamnya dan tersebar secara luas pada setiap pulau-pulau di Indonesia. Kekayaan alam yang dimiliki tersebut dapat menjadi modal bagi pelaksanaan pembangunan ekonomi bagi Indonesia. Sumber kekayaan alam yang dimiliki Indonesia tersebut dapat dioptimalkan salah 
Tabel 1. Tingkat Penyerapan Tenaga Kerja di Indonesia (Persen), 2005-2015

\begin{tabular}{cccc}
\hline Tahun & $\begin{array}{c}\text { Total Angkatan } \\
\text { Kerja (\%) }\end{array}$ & $\begin{array}{c}\text { Persentase dari Total Angkatan } \\
\text { Kerja yang Bekerja Pada Sektor } \\
\text { Pertanian (Persen) }\end{array}$ & $\begin{array}{c}\text { Persentase dari Total Angkatan } \\
\text { Kerja yang Bekerja Pada Sektor } \\
\text { Non Pertanian (Persen) }\end{array}$ \\
\hline 2005 & 68,02 & 44,03 & 55,96 \\
2006 & 66,74 & 44,46 & 55,53 \\
2007 & 66,60 & 43,66 & 56,33 \\
2008 & 67,33 & 41,83 & 58,16 \\
2009 & 67,60 & 41,18 & 58,81 \\
2010 & 67,83 & 39,87 & 60,12 \\
2011 & 70,01 & 37,89 & 62,10 \\
2012 & 69,59 & 36,52 & 63,47 \\
2013 & 69,15 & 35,16 & 64,83 \\
2014 & 69,17 & 34,55 & 65,44 \\
2015 & 69,50 & 33,20 & 66,79 \\
\hline
\end{tabular}

Sumber: Badan Pusat Statistik, diolah

satunya melalui sektor pertanian (komoditas primer).

Sektor pertanian masih menjadi andalan penciptaan lapangan pekerjaan dalam jumlah yang cukup besar. Tabel 1 menunjukkan, persentase total angkatan kerja yang bekerja pada sektor pertanian dari tahun 2005 sampai tahun 2015, di mana ratarata $40 \%$ dari total angkatan kerja bekerja di sektor pertanian, sedangkan sisanya sebesar $55 \%$ bekerja di sektor non pertanian yang tersebar di 8 sektor perekonomian di Indonesia. Hal ini berarti persentase angkatan kerja di sektor pertanian masih cukup tinggi dibandingkan dengan persentase sektor non pertanian.

Kekayaan sumber daya alam di Indonesia seharusnya dapat menjadi peluang untuk mengembangkan sektor pertanian, sehingga dapat menopang kehidupan masyarakat. Akan tetapi, kenyataannya sektor pertanian di Indonesia masih kurang berkembang. Hal ini dilihat dari kontribusi sektor pertanian terhadap pendapatan nasional yang dilihat berdasarkan Produk Domestik Bruto (PDB) dan kenyataannya kontribusi sektor pertanian PDB tidak terlalu besar. Tabel 2 menunjukkan bahwa pertumbuhan sektor pertanian tahun 2005-2014 bersifat berfluktuatif dan cenderung mengalami peningkatan. Walaupun demikian, pertumbuhan sektor pertanian masih berada di bawah pertumbuhan PDB nasional dan masih rendah dibandingkan dengan sektorsektor lainnya.

Berdasarkan tabel 2, sumbangan PDB terbesar yaitu sektor pengangkutan dan komunikasi; keuangan, real estat, dan jasa perusahaan; konstruksi. Sektor-sektor tersebut dianggap sebagai motor penggerak bagi pertumbuhan perekonomian dibandingkan dengan sektor pertanian. Hal ini dapat dilihat dari kontribusi sektor pengangkutan dan komunikasi; sektor keuangan, real estat, dan jasa perusahaan; sektor konstruksi terhadap PDB (Lihat Tabel 2 ) yang nilainya berada di atas rata-rata PDB. Walaupun sektor pengangkutan dan komunikasi menyumbang PDB terbesar pada setiap tahunnya dari tahun 2005-2014 dalam 
Tabel 2. Laju Pertumbuhan Produk Domestik Bruto Atas Dasar Harga Konstan 2000 Menurut Lapangan Usaha (Persen), 2005-2014

\begin{tabular}{|l|c|c|c|c|c|c|c|c|c|c|}
\hline \multicolumn{1}{|c|}{ Lapangan Usaha } & 2005 & 2006 & 2007 & 2008 & 2009 & 2010 & 2011 & 2012 & 2013 & 2014 \\
\hline $\begin{array}{l}\text { Pertanian, Peternakan, } \\
\text { Kehutanan, dan Perikanan }\end{array}$ & 2.72 & 3.36 & 3.47 & 4.83 & 3.96 & 3.01 & 3.37 & 4.20 & 3.44 & 3.29 \\
\hline $\begin{array}{l}\text { Pertambangan dan } \\
\text { Penggalian }\end{array}$ & 3.20 & 1.70 & 1.93 & 0.71 & 4.47 & 3.86 & 1.60 & 1.58 & 1.41 & -0.2 \\
\hline Indutsri Pengolahan & 4.60 & 4.59 & 4.67 & 3.66 & 2.21 & 4.74 & 6.14 & 5.74 & 5.56 & 4.86 \\
\hline Listrik, Gas, dan Air Bersih & 6.30 & 5.76 & 10.33 & 10.93 & 14.29 & 5.33 & 4.71 & 6.32 & 5.78 & 5.50 \\
\hline Konsruksi/Bangunan & 7.54 & 8.34 & 8.53 & 7.55 & 7.07 & 6.95 & 6.07 & 7.39 & 6.57 & 6.58 \\
\hline $\begin{array}{l}\text { Perdagangan Hotel, dan } \\
\text { Restoran }\end{array}$ & 8.30 & 6.42 & 8.93 & 6.87 & 1.28 & 8.69 & 9.24 & 8.16 & 5.89 & 4.64 \\
\hline $\begin{array}{l}\text { Pengangkutan dan } \\
\text { Komunikasi }\end{array}$ & 12.76 & 14.23 & 14.04 & 16.57 & 15.85 & 13.41 & 10.70 & 9.98 & 9.80 & 9.31 \\
\hline $\begin{array}{l}\text { Keuangan, Real Estat, dan } \\
\text { Jasa Perusahaan }\end{array}$ & 6.70 & 5.47 & 7.99 & 8.24 & 5.21 & 5.67 & 6.84 & 7.14 & 7.57 & 5.96 \\
\hline Jasa-Jasa & 5.16 & 6.16 & 6.44 & 6.24 & 6.42 & 6.04 & 6.80 & 5.22 & 5.47 & 5.92 \\
\hline Produk Domestik Broto & 5.69 & 5.50 & 6.35 & 6.01 & 4.63 & 6.22 & 6.49 & 6.26 & 5.73 & 5.06 \\
\hline
\end{tabular}

Sumber: Badan Pusat Statistik, diolah

suatu pelaksanaan pembangunan di Indonesia, hal ini tidak dapat terlepas dari peran sektor pertanian dan sektor-sektor lainnya. Dengan kata lain, walaupun sektor pertanian di Indonesia masih tergolong rendah dalam menyumbang PDB tetapi sektor pertanian memainkan peranan penting dalam proses pembangunan ekonomi Indonesia. Sektor pertanian dapat menjadi sektor pendukung maupun penunjang dalam pembangunan sektorsektor lainnya. Oleh karena itu, peran sektor pertanian diharapkan tidak hanya dilihat dari kontribusinya terhadap PDB, akan tetapi sektor pertanian dapat berperan terkait pengaruhnya terhadap sektor-sektor lain sebagai penyedia input (barang dan jasa) antara sektor lainnya yang pada akhirnya dapat mempengaruhi pertumbuhan ekonomi nasional.

Peran sektor pertanian terhadap sektorsektor lainnya dalam perekonomian dengan menggunakan alat analisis Input Output sudah pernah dilakukan oleh beberapa peneliti sebelumnya. Sukanto (2010) dengan judul Peranan Sektor Pertanian Terhadap Perekonomian Jawa Tengah (Pendekatan Analisis Input-Output). Hasilnya menunjukkan keterkaitan sektor pertanian lebih banyak menunjukkan keterkaitan langsung ke depan yang lebih besar dibandingkan dengan keterkaitan langsung ke belakang. Angka keterkaitan ke belakang yang paling besar adalah sub sektor bahan makanan dan tebu. Suryani (2013) meneliti Analisis Peran Sektor Ekonomi Terhadap Pertumbuhan Ekonomi Kabupaten Pemalang. Hasil penelitian menunjukkan bahwa sektor listrik, gas, dan air bersih; pengangkutan dan komunikasi memiliki angka keterkaitan ke depan dan ke belakang yang lebih tinggi dibanding sektor lainnya. Astrini (2013) meneliti Analisis Revitalisasi Sektor Pertanian dalam Pembangunan Terhadap Perekonomian di Jawa Timur Melalui Pendekatan Input-Output. Hasil 
penelitian menunjukkan bahwa sektor yang memiliki keterkaitan ke depan dan belakang sekaligus menjadi sektor unggulan di Provinsi Jawa Timur adalah sektor listrik, gas, dan air bersih; sektor keuangan, persewaan, dan jasa perusahaan. Secara keseluruhan peneliti tersebut meneliti peran sektor pertanian dalam ruang lingkup wilayah atau daerah. Peneliti ini mencoba meneliti sektor pertanian dalam ruang lingkup nasional.

Tujuan penelitian ini akan membahas dua hal untuk melihat keterkaitan ke depan dan ke belakang sektor pertanian dengan sektorsektor lain dalam perekonomian Indonesia dan melihat dampak pengganda dari sektor pertanian dalam meningkatkan pertumbuhan ekonomi, meningkatkan pendapatan, dan meningkatkan penyerapan tenaga kerja sektor-sektor lain dalam perekonomian.

\section{METODE}

Jenis data yang digunakan adalah data sekunder dari Tabel Input-Output Indonesia Tahun 2010: Transaksi Domestik Atas Dasar Harga Produsen (Juta Rupiah) Klasifikasi 17 Sektor. Data tabel Input-Output diklasifikasi 17 sektor tersebut diagregasikan menjadi 9 sektor. Metode analisis yang digunakan merupakan metode analisis Input-Output. Analisis ini bisa dibedakan menjadi dua, yaitu untuk melihat keterkaitan ke depan dan ke belakang, dan untuk melihat angka pengganda.

Keterkaitan ke depan adalah menghitung total output yang tercipta akibat meningkatnya output suatu sektor industri melalui mekanisme distribusi output dalam perekonomian. Jika terjadi peningkatan output produksi sektor i, maka tambahan output tersebut akan didistribusikan ke sektor-sektor produksi di perekonomian tersebut, termasuk sektor i itu sendiri. Secara langsung, jika terjadi peningkatan satu unit output sektor $\mathrm{i}$, peningkatan output total di perekonomian, yang melalui mekanisme output, ditunjukkan oleh baris dari matriks $A$. Oleh karena iitu, keterkaitan ke depan langsung sektor $\mathrm{j}$, yang dinotasikan dengan $F(d)$, diformulasikan sebagai:

$\mathrm{F}(\mathrm{d}) \mathrm{i}=\sum_{j=1}^{n} a i j$

Yang mana aij adalah elemen matrik $A$. Selanjutnya peningkatan tidak hanya berhenti di situ saja. Ada pula efek lanjutan dari peningkatan output tadi yaitu efek tidak langsung yang terekam dalam matrik kebalikan output (1-A) $)^{-1}$. Keterkaitan ke depan total dari sektor i yaitu penjumlahan dari efek keterkaitan langsung dan tidak langsung ke depan, yang dinotasikan dengan $F(d+i)$, diformulasikan sebagai: $\mathrm{F}(\mathrm{d}+\mathrm{i}) \mathrm{i}=\sum_{j=1}^{n} a i j$

Keterkaitan ke Belakang (Backward Linkages) adalah menghitung peningkatan output sektor tertentu yang akan mendorong peningkatan output sektor-sektor lainnya. Peningkatan output sektor-sektor lainnya tersebut dapat terlaksana melalui dua cara, pertama peningkatan output sektor i akan meningkatkan permintaan input sektor $i$ tersebut. Input sektor i tadi ada yang berasal dari sektor i sendiri, ada pula yang berasal dari sektor lain, misalnya sektor j. Oleh karenanya, sektor i akan menerima output sektor j lebih banyak daripada sebelumnya (untuk digunakan sebagai input proses produksi). Berarti, harus ada peningkatan output sektor $\mathrm{j}$. Peningkatan output sektor $\mathrm{j}$ ini, pada gilirannya, akan meningkatkan 
permintaan input sektor $\mathrm{j}$ itu sendiri, yang berarti harus ada peningkatan output sektorsektor lainnya. Begitu seterusnya, terjadi keterkaitan antar sektor-sektor industri tersebut. Keterkaitan antara sektor-sektor industri yang seperti itu disebut dengan keterkaitan ke belakang karena keterkaitannya bersumber dari input produksi. Secara singkat, keterkaitan ke belakang langsung ini, yang dinotasikan dengan $\mathrm{B}(\mathrm{d})$ dirumuskan sebagai berikut:

$\mathrm{B}(\mathrm{d}) \mathrm{j}=\sum_{i=1}^{n} a i j$

Selanjutnya, keterkaitan ke belakang tersebut tidak saja memiliki efek langsung seperti yang ditunjukkan di atas, namun juga memiliki efek tidak langsung dari penambahan output (secara eksogen), yang ditunjukkan oleh matriks Kebalikan Leontief. Keterkaitan ke belakang total dari sektor i yaitu penjumlahan dari efek keterkaitan langsung dan tidak langsung kebelakang, yang dinotasikan dengan B $(d+i)$, diformulasikan sebagai:

$\mathrm{B}(\mathrm{d}+\mathrm{i}) \mathrm{j}=\sum_{i=1}^{n} a i j$

Angka pengganda output terjadi jika ada peningkatan permintaan akhir (final demand) pada suatu sektor yang akan meningkatkan output itu sendiri dan sektorsektor lain dalam perekonomian. Besarnya kelipatan perubahan output regional akibat perubahan permintaan akhir suatu sektor dikenal dengan istilah angka pengganda output. Dengan kata lain, angka pengganda output (suatu sektor) adalah nilai total dari output yang dihasilkan oleh perekonomian untuk memenuhi (atau akibat) adanya perubahan satu unit uang permintaan akhir sektor tersebut. Besarnya angka pengganda output untuk sektor ke-n di dalam perekonomian dihitung dari jumlah kolom ke-n dari matriks Kebalikan Leontief untuk perekonomian yang bersangkutan. Sehingga, dengan menggunakan notasi aij bagi elemen matriks Kebalikan Leontief tersebut, angka pengganda output didefinisikan:

$\mathrm{Oj}=\sum_{i=1}^{n} a i j$

Angka pengganda pendapatan terjadi ketika ada perubahan (peningkatan) permintaan akhir suatu sektor juga akan meningkatkan pendapatan masyarakat. Besarnya pelipatgandaan peningkatan ini dapat dilihat dari angka pengganda pendapatan. Angka pendapatan rumah tangga suatu sektor menunjukkan jumlah pendapatan rumah tangga total yang tercipta akibat adanya tambahan satu unit uang permintaan akhir di sektor tersebut. Angka pengganda pendapatan rumah tangga ini diterjemahkan sebagai peningkatan permintaan akhir dalam bentuk rumah tangga. Jika angka pengganda pendapatan rumah tangga sektor $\mathrm{j}$ dinotasikan dengan $\mathrm{Hj}$ maka dapat dituliskan:

$\mathrm{Hj}=\sum_{i=1}^{n}$ an $+1, j a i j$

Angka pengganda kesempatan kerja terjadi ketika terdapat perubahan kesempatan kerja sebagai akibat adanya peningkatan produksi. Besarnya efek tersebut dapat diperhitungkan dari angka pengganda kesempatan kerja. Angka pengganda kesempatan kerja merupakan efek total dari perubahan lapangan pekerjaan di perekonomian akibat adanya satu unit uang perubahan permintaan akhir di suatu sektor. Untuk dapat menangkap perubahan permintaan akhir di suatu sektor produksi terhadap perubahan lapangan pekerjaan di seluruh perekonomian, 
diperlukan jumlah lapangan pekerjaan awal, atau jumlah tenaga kerja awal pada masingmasing sektor produksi yang memang telah digunakan untuk melakukan proses produksi selama ini. Data tersebut digunakan untuk menghitung berapa kontribusi setiap pekerja, secara rata-rata, dalam memproduksi output sektornya masingmasing. Jika nilai rata-rata output setiap pekerja di sektor j dinotasikan dengan wj, maka diperoleh:

\section{$\mathrm{Ej}=\sum_{i=1}^{n} w n+1, j a i j$}

Secara singkat angka pengganda kesempatan kerja diperoleh dari perkalian antara koefisien tenaga kerja dengan angka pengganda outputnya di mana nilai koefisien tenaga kerja merupakan rasio antara jumlah tenaga kerja sektoral dengan nilai inputnya.

\section{HASIL DAN PEMBAHASAN}

Keterkaitan ke depan langsung sektor pertanian dengan sektor lainnya dapat dihitung dari nilai koefisien matriks, sedangkan untuk melihat keterkaitan ke depan tidak langsung dapat dilihat dari matriks kebalikan Leontif. Semakin besar nilai koefisien teknis maupun matrik Kebalikan Leontif pada keterkaitan ke depan langsung maupun tidak langsung antara sektor pertanian dengan sektor tertentu maka semakin besar pula keterkaitan ke depan antara sektor pertanian dengan sektor tertentu tersebut. Artinya semakin besar pula ketergantungan sektor tertentu tersebut terhadap sektor pertanian dalam hal penyediaan bahan baku untuk proses produksi. Hasil perhitungan keterkaitan ke depan langsung dan keterkaitan ke depan tidak langsung dapat dilihat pada Tabel 3.

Tabel 3 menunjukkan keterkaitan ke depan langsung, tidak langsung, dan total. Nilai rata-rata keterkaitan ke depan langsung sebesar 0,412. Nilai keterkaitan ke depan langsung yang lebih besar dari nilai rata-rata

Tabel 3. Keterkaitan Ke Depan

\begin{tabular}{|c|c|c|c|c|c|c|}
\hline \multirow{3}{*}{ Sektor } & \multicolumn{6}{|c|}{ Sektor Pertanian } \\
\hline & \multicolumn{6}{|c|}{ Keterkaitan ke Depan } \\
\hline & Langsung & Peringkat & $\begin{array}{c}\text { Tidak } \\
\text { Langsung }\end{array}$ & Peringkat & Total & Peringkat \\
\hline $\begin{array}{l}\text { Pertambangan dan } \\
\text { Penggalian }\end{array}$ & 0,585 & 2 & 1,081 & 6 & 1,665 & 3 \\
\hline Industri Pengolahan & 0,480 & 4 & 2,488 & 1 & 2,968 & 1 \\
\hline $\begin{array}{l}\text { Listrik, Gas, dan Air } \\
\text { Bersih }\end{array}$ & 0,713 & 1 & 1,206 & 3 & 1,919 & 2 \\
\hline Bangunan & 0,088 & 8 & 1,122 & 4 & 1,210 & 7 \\
\hline $\begin{array}{l}\text { Perdagangan, Hotel, } \\
\text { dan Restoran }\end{array}$ & 0,417 & 5 & 1,091 & 5 & 1,508 & 5 \\
\hline $\begin{array}{l}\text { Pengangkutan dan } \\
\text { Komunikasi }\end{array}$ & 0,414 & 6 & 1,226 & 2 & 1,641 & 4 \\
\hline $\begin{array}{l}\text { Keuangan, Persewaan, } \\
\text { Jasa Perusahaan }\end{array}$ & 0,492 & 3 & 0,999 & 8 & 1,491 & 6 \\
\hline Jasa-Jasa & 0,109 & 7 & 1,017 & 7 & 1,127 & 8 \\
\hline Rata-Rata & 0,412 & & 1,279 & & 1,691 & \\
\hline
\end{tabular}

Sumber: Tabel Input-Output Indonesia Tahun 2010, Klasifikasi 9 sektor (diolah) 
keterkaitan ke depan langsung antar sektor pertanian yaitu sektor listrik, gas, dan air bersih sebesar 0,713 ; sektor pertambangan dan penggalian sebesar 0,585; sektor keuangan, persewaan, jasa perusahaan sebesar 0,492; sektor industri pengolahan sebesar 0,480; sektor perdagangan, hotel, dan restoran sebesar 0,418; dan sektor pengangkutan dan komunikasi sebesar 0,414 . Hal ini artinya keterkaitan antara sektor pertanian dengan sektor listrik, gas, dan air bersih; sektor pertambangan dan penggalian sebesar; sektor keuangan, persewaan, jasa perusahaan sebesar; sektor industri pengolahan; sektor perdagangan, hotel, dan restoran; dan sektor pengangkutan dan komunikasi memiliki keterkaitan ke depan langsung yang tinggi. Nilai keterkaitan ke depan langsung tersebut memiliki arti, misalnya nilai keterkaitan ke depan langsung sektor pertanian dengan sektor listrik, gas, dan air bersih sebesar 0,713 . Nilai 0,713 ini berarti bahwa apabila terjadi perubahan atau peningkatan 1 unit uang output sektor listrik, gas, dan air bersih akan meningkatkan output perekonomian (termasuk sektor listrik, gas, dan air bersih) sebesar 0.713 unit uang (Rp) secara langsung atau tidak langsung melalui jalur peningkatan output sektor listrik, gas, dan air bersih yang digunakan sebagai input oleh sektor lain. Dengan demikian pembangunan yang diarahkan kepada pengembangan sektor listrik, air bersih, dan gas akan berdampak langsung terhadap pembangunan sektor pertanian.

Nilai rata-rata keterkaitan ke depan tidak langsung sebesar 1,279. Nilai keterkaitan ke depan tidak langsung yang lebih besar dari nilai rata-rata keterkaitan ke depan tidak langsung antar sektor pertanian yaitu sektor industri pengolahan sebesar 2,488. Hal ini artinya keterkaitan antara sektor pertanian dengan sektor industri pengolahan memiliki keterkaitan ke depan tidak langsung yang tinggi. Nilai keterkaitan ke depan tidak langsung sektor pertanian dengan sektor industri pengolahan sebesar 2,488. Nilai 2,488 ini berarti bahwa apabila terjadi perubahan atau peningkatan 1 unit uang output sektor industri pengolahan akan meningkatkan output perekonomian (termasuk sektor industri pengolahan) sebesar 2,488 unit uang (Rp) secara langsung, melalui jalur peningkatan output sektor industri pengolahan yang digunakan sebagai input oleh sektor lain. Dengan demikian pembangunan yang diarahkan kepada pengembangan sektor industri pengolahan akan berdampak tidak langsung terhadap pembangunan sektor pertanian.

Nilai rata-rata keterkaitan ke total sebesar 1,691. Nilai keterkaitan ke depan total yang lebih besar dari nilai rata-rata keterkaitan ke depan total antar sektor pertanian yaitu sektor industri pengolahan sebesar 2,968 dan sektor listrik, gas, dan air bersih sebesar 1,919. Hal ini artinya keterkaitan antara sektor pertanian dengan sektor industri pengolahan dan sektor listrik, gas, dan air bersih memiliki keterkaitan ke depan total yang tinggi. Nilai keterkaitan ke depan total sektor pertanian dengan sektor industri pengolahan sebesar 2,968. Nilai 2,968 ini berarti bahwa apabila terjadi perubahan atau peningkatan 1 unit uang output sektor industri pengolahan akan meningkatkan output perekonomian (termasuk sektor industri pengolahan) sebesar 2,968 unit uang (Rp) secara langsung 
dan tidak langsung, melalui jalur peningkatan output sektor industri pengolahan yang digunakan sebagai input oleh sektor lain. Dengan demikian pembangunan yang diarahkan kepada pengembangan sektor industri pengolahan akan berdampak langsung dan tidak langsung terhadap pembangunan sektor pertanian.

Identifikasi dari sektor yang memiliki keterkaitan ke depan yang tinggi terhadap sektor pertanian tersebut mengindikasikan bahwa output dari sektor industri pengolahan dan sektor listrik, gas, dan air bersih yang diproduksi, sebagian besar digunakan sebagai input oleh sektor pertanian di Indonesia. Keadaan ini menunjukkan bahwa sektor industri pengolahan dan sektor listrik, gas, dan air bersih memiliki peranan yang penting dalam mendorong pertumbuhan produksi sektorsektor pertanian dan memberikan ketersediaan output yang digunakan sebagai input oleh sektor pertanian di Indonesia. Kondisi ini sejalan dengan teori Hrirschman, yang menyatakan bahwa pertumbuhan yang cepat dari satu atau beberapa industri dapat mendorong perluasan industri-industri lainnya yang terkait dengan sektor industri yang tumbuh lebih dahulu. Dalam sektor produksi mekanisme pendorong pembangunan yang tercipta sebagai akibat dari adanya hubungan antara berbagai industri dalam menyediakan barang-barang yang diperlukan sebagai bahan baku bagi industri lainnya (Arsyad, 2010).

Keterkaitan ke belakang langsung antara sektor pertanian dengan sektor lainnya dapat dihitung dari nilai koefisien matriks, sedangkan untuk melihat keterkaitan ke belakang tidak langsung dapat dilihat dari matriks kebalikan Leontif. Semakin besar nilai koefisien teknis maupun matrik Kebalikan Leontif keterkaitan ke belakang langsung dan tidak langsung antara sektor pertanian dengan sektor tertentu maka semakin besar pula keterkaitan antar sektor tersebut. Semakin besar keterkaitan ke belakang antara sektor pertanian dengan sektor tertentu tersebut maka semakin besar pula ketergantungan sektor pertanian dalam menggunakan output yang dihasilkan oleh sektor tertentu untuk digunakan sebagai input dalam proses produksi sektor pertanian. Hasil perhitungan keterkaitan ke belakang langsung dan keterkaitan ke belakang tidak langsung dapat dilihat pada Tabel 4.

Tabel 4 menunjukkan keterkaitan ke belakang langsung, tidak langsung, dan total. Nilai rata-rata keterkaitan ke belakang langsung sebesar 0,410 . Nilai keterkaitan ke belakang langsung yang lebih besar dari nilai rata-rata keterakitan ke belakang langsung antar sektor pertanian yaitu sektor listrik, gas, dan air bersih sebesar 0,729; sektor bangunan sebesar 0,585; sektor industri pengolahan sebesar 0,439; sektor pengangkutan dan komunikasi sebesar 0,429 . Hal ini artinya keterkaitan antara sektor pertanian dengan sektor listrik, gas, dan air bersih; sektor bangunan, sektor industri pengolahan; dan sektor pengangkutan dan komunikasi memiliki keterkaitan ke belakang langsung yang tinggi. Nilai keterkaitan ke belakang langsung tersebut memiliki arti, misalnya nilai keterkaitan ke belakang langsung sektor pertanian dengan sektor listrik, gas, dan air bersih sebesar 0,729. Nilai 0,729 ini berarti bahwa apabila terjadi perubahan atau 1 unit 
Tabel 4. Keterkaitan Ke Belakang

\begin{tabular}{|c|c|c|c|c|c|c|}
\hline \multirow{3}{*}{ Sektor } & \multicolumn{6}{|c|}{ Sektor Pertanian } \\
\hline & \multicolumn{6}{|c|}{ Keterkaitan ke Belakang } \\
\hline & Langsung & Peringkat & $\begin{array}{c}\text { Tidak } \\
\text { Langsung }\end{array}$ & Peringkat & Total & Peringkat \\
\hline $\begin{array}{l}\text { Pertambangan dan } \\
\text { Penggalian }\end{array}$ & 0,274 & 8 & 1,141 & 8 & 1,415 & 8 \\
\hline Industri Pengolahan & 0,439 & 3 & 1,261 & 5 & 1,700 & 4 \\
\hline $\begin{array}{l}\text { Listrik, Gas, dan Air } \\
\text { Bersih }\end{array}$ & 0,729 & 1 & 1,822 & 1 & 2,552 & 1 \\
\hline Bangunan & 0,585 & 2 & 1,365 & 2 & 1,950 & 2 \\
\hline $\begin{array}{l}\text { Perdagangan, Hotel, } \\
\text { dan Restoran }\end{array}$ & 0,350 & 6 & 1,223 & 6 & 1,573 & 6 \\
\hline $\begin{array}{l}\text { Pengangkutan dan } \\
\text { Komunikasi }\end{array}$ & 0,429 & 4 & 1,271 & 3 & 1,700 & 3 \\
\hline $\begin{array}{l}\text { Keuangan, Persewaan, } \\
\text { Jasa Perusahaan }\end{array}$ & 0,301 & 7 & 1,182 & 7 & 1,483 & 7 \\
\hline Jasa-Jasa & 0,408 & 5 & 1,262 & 4 & 1,670 & 5 \\
\hline Rata-Rata & 0,410 & & 1,292 & & 1,701 & \\
\hline
\end{tabular}

Sumber: Tabel Input-Output Indonesia Tahun 2010, Klasifikasi 9 sektor (diolah)

uang output sektor listrik, gas, dan air bersih akan meningkatkan permintaan inputnya secara langsung dari sektor-sektor dalam perekonomian (termasuk sektor listrik, gas, dan air bersih) sebesar 0.729 unit uang (Rp). Untuk memenuhi permintaan sektor listrik, gas, dan air bersih, sektor-sektor dalam perekonomian (termasuk sektor listrik, gas, dan air bersih) akan meningkatkan produksinya. Dengan demikian pembangunan yang diarahkan kepada pengembangan sektor listrik, air bersih, dan gas akan berdampak langsung terhadap pembangunan sektor pertanian.

Nilai rata-rata keterkaitan ke belakang tidak langsung sebesar 1,292. Nilai keterkaitan ke belakang tidak langsung yang lebih besar dari nilai rata-rata keterkaitan ke belakang tidak langsung antar sektor pertanian yaitu sektor listrik, gas, dan air bersih sebesar 1,822 dan sektor bangunan sebesar 1,365. Hal ini artinya keterkaitan antara sektor pertanian dengan sektor listrik, gas, dan air bersih memiliki keterkaitan ke belakang tidak langsung yang tinggi. Nilai keterkaitan ke belakang tidak langsung sektor pertanian dengan sektor listrik, gas, dan air bersih sebesar 1,822. Nilai 1,822 ini berarti bahwa apabila terjadi perubahan atau peningkatan 1 unit uang output sektor listrik, gas, dan air bersih akan meningkatkan permintaan inputnya secara tidak langsung dari sektor-sektor dalam perekonomian (termasuk sektor listrik, gas, dan air bersih sendiri) sebesar 1,822 unit uang (Rp). Untuk memenuhi permintaan sektor listrik, gas, dan air bersih, sektor-sektor dalam perekonomian (termasuk sektor listrik, gas, dan air bersih) akan meningkatkan produksinya. Dengan demikian pembangunan yang diarahkan kepada pengembangan sektor listrik, gas, dan air bersih akan berdampak tidak langsung terhadap pembangunan sektor pertanian. 
Nilai rata-rata keterkaitan ke belakang total sebesar 1,701. Nilai keterkaitan ke belakang total yang lebih besar dari nilai ratarata keterkaitan ke belakang total antar sektor pertanian yaitu sektor listrik, gas, dan air bersih sebesar 2,552 dan sektor bangunan sebesar 1,950. Hal ini artinya keterkaitan antara sektor pertanian dengan sektor listrik, gas, dan air bersih memiliki keterkaitan ke belakang total yang tinggi. Nilai keterkaitan ke belakang total sektor pertanian dengan sektor listrik, gas, dan air bersih sebesar 2,552. Nilai 2,552 ini berarti bahwa apabila terjadi perubahan atau peningkatan 1 unit uang output sektor listrik, gas, dan air bersih akan meningkatkan permintaan inputnya secara langsung dan tidak langsung dari sektor-sektor dalam perekonomian (termasuk sektor listrik, gas, dan air bersih sendiri) sebesar 2,552 unit uang (Rp). Untuk memenuhi permintaan sektor listrik, gas, dan air bersih, sektor-sektor dalam perekonomian (termasuk sektor listrik, gas, dan air bersih) akan meningkatkan produksinya. Dengan demikian pembangunan yang diarahkan kepada pengembangan sektor listrik, gas, dan air bersih akan berdampak langsung dan tidak langsung terhadap pembangunan sektor pertanian.

Identifikasi dari sektor yang memiliki keterkaitan ke belakang yang tinggi terhadap sektor pertanian tersebut mengindikasikan bahwa output dari sektor listrik, gas, dan air bersih dan sektor bangunan yang diproduksi, sebagian besar digunakan sebagai input oleh sektor pertanian di Indonesia. Keadaan ini menunjukkan bahwa sektor listrik, gas, dan air bersih dan sektor bangunan memiliki peranan yang penting dalam mendorong pertumbuhan produksi sektor pertanian dan memberikan ketersediaan output yang digunakan sebagai input oleh sektor-sektor lain dalam perekonomian di Indonesia.

Analisis selanjutnya yaitu analisis pengganda yang digunakan untuk melihat dampak perubahan dari peningkatan permintaan akhir suatu sektor yang pengaruhnya terhadap pertumbuhan output, pendapatan rumah tangga, dan

Tabel 5. Angka Pengganda Output, Pendapatan, dan Kesempatan Kerja

\begin{tabular}{cccccccccc}
\hline Sektor & $1 \mathrm{n}$ & $2 \mathrm{n}$ & $3 \mathrm{n}$ & $4 \mathrm{n}$ & $5 \mathrm{n}$ & $6 \mathrm{n}$ & $7 \mathrm{n}$ & $8 \mathrm{n}$ & $9 \mathrm{n}$ \\
\hline Output & 1,270 & 1,415 & 1,700 & 2,551 & 1,950 & 1,572 & 1,699 & 1,482 & 1,669 \\
Pendapatan & 0,207 & 0,120 & 0,108 & 0,062 & 0,137 & 0,195 & 0,161 & 0,155 & 0,463 \\
Kesempatan Kerja & 0,034 & 0,001 & 0,003 & 0,007 & 0,003 & 0,016 & 0,004 & 0,002 & 0,015 \\
\hline
\end{tabular}

Sumber: Tabel Input-Output Indonesia Tahun 2010, Klasifikasi 9 sektor (diolah)

Keterangan:

1. : Pertanian, Kehutanan, dan Perikanan

2. : Pertambangan dan Penggalian

3. : Industri Pengolahan

4. : Listrik, Gas, dan Air Bersih

5. : Bangunan

6. : Perdagangan, Hotel, dan Restoran

7. : Pengangkutan dan Komunikasi

8. : Keuangan, Persewaan, dan Jasa Perusahaan

9. : Jasa-Jasa 
tenaga kerja seluruh sektor perekonomian. Tabel 5 menunjukkan hasil angka pengganda output, pengganda pendapatan, dan kesempatan kerja sektor pertanian.

Berdasarkan Tabel 5, sektor pertanian memiliki nilai pengganda output sebesar 1,270. Nilai 1,270 ini berarti bahwa peningkatan permintaan akhir sebesar satu unit uang di sektor 1 (pertanian, kehutanan, dan perikanan) maka akan meningkatkan tambahan output seluruh perekonomian sebesar 1,270 unit uang (Rp) akibat peningkatan permintaan akhir tersebut. Nilai pengganda output tersebut sangat rendah jika dibandingkan dengan sektor-sektor lainnya dalam perekonomian. Sektor pertanian berada di urutan ke delapan yang artinya sektor pertanian memiliki kemampuan dalam mendorong atau merangsang tambahan output dalam perekonomian sangat rendah di lindonesia. Hal ini disebabkan karena masih terbatasnya sarana dan prasarana yang ada di sektor pertanian.

Berdasarkan laporan dari Kementerian Pertanian tahun 2015, alat yang digunakan para petani dalam menghasilkan suatu output masih sederhana. Kesederhanaan alat ini memerlukan waktu yang cukup lama dalam menghasilkan output bahan pangan maupun output di perikanan di Indonesia. Selain itu, disebabkan oleh masih belum maksimalnya sarana pengelolaan lahan dan air, modal yag dimiliki oleh petani terbatas, penyediaan pupuk pestisida, fasilitas penyediaan mesin pertanian dan alat untuk mengangkap hasil ikan masih minim. Maka dari berdampak pada hasil output atau produksi yang dihasilkan sektor pertanian di Indonesia masih rendah.
Nilai angka pengganda pendapatan di sektor pertanian pada tabel 5 sebesar 0,207. Nilai 0,207 ini berarti bahwa untuk peningkatan permintaan akhir sebesar 1 unit uang di sektor $1 \mathrm{n}$ (pertanian, kehutanan, dan perikanan) akan menyebabkan peningkatan pendapatan rumah tangga dalam perekonomian sebesar 0,207 unit uang (Rp). Nilai angka pengganda pendapatan rumah tangga di sektor pertanian memiliki nilai yang lebih tinggi dibandingkan sektor-sektor lainnya dalam perekonomian. Artinya pengalokasian gaji dan upah di sektor pertanian memiliki kemampuan dalam mendorong atau merangsang pertumbuhan seluruh sektor dalam perekonomian sangat cepat.

Hasil tersebut memperlihatkan bahwa sektor pertanian bisa dijadikan peluang oleh para petani untuk mendapatkan pendapatan. Adanya kesempatan bekerja di sektor pertanian untuk memperoleh pendapatan akan mampu mendorong para petani untuk dapat bekerja di sektor tersebut sehingga pada akhirnya kontribusi tenaga kerja nya akan meningkat, hasil output yang diperoleh pun akan meningkat, dan para petani mempunyai pendapatan. Hal tersebut juga dapat diketahui bahwa saat terjadi peningkatan permintaan pada sektor pertanian terutama hasil dari output atau hasil dari produksi, maka akan meningkatkan pendapatan akibat tercapainya hasil output yang maksimal. Maka dengan adanya sektor pertanian terhadap angka pengganda pendapatan memperlihatkan bahwa akibat dari peningkatan permintaan akhir pada sektor pertanian akan menciptakan pertumbuhan output untuk seluruh perekonomian di Indonesia. 
Nilai angka pengganda kesempatan kerja di sektor pertanian pada Tabel 5 sebesar 0,034 . Nilai 0,034 ini berarti bahwa untuk peningkatan permintaan akhir sebesar 1 unit uang di sektor 1n (pertanian, kehutanan, dan perikanan) akan menyebabkan peningkatan kesempatan kerja dalam perekonomian sebesar 0,034 orang. Dengan mengalikan dengan 100, maka peningkatan permintaan akhir sebesar 100 unit uang pada sektor $1 \mathrm{n}$ (pertanian, kehutanan, dan perikanan) akan meningkatkan lapangan pekerjaan bagi 3,4 orang dalam perekonomian tersebut. Nilai angka pengganda kesempatan kerja di sektor pertanian memiliki nilai yang lebih tinggi dibandingkan sektor-sektor lainnya dalam perekonomian. Artinya sektor pertanian memiliki kemampuan dalam menciptakan lapangan kerja lebih cepat dibandingkan sektor lainnya.

Peran penting dari sektor pertanian sebagai sektor tempat mayoritas tenaga kerja Indonesia memperoleh penghasilan untuk hidup mengindikasikan bahwa sektor pertanian merupakan sektor yang memiliki kontribusi terbesar dalam proses penyeraoan tenaga kerja di Indonesia. Hal ini terbukti dari data penyerapan tenaga kerja di Indonesia yang menunjukkan bahwa sektor pertanian merupakan sektor yang memiiki kontribusi terbesar pertama dalam penyerapan tenaga kerja yakni menyerap tenaga kerja sebesar 33,20\% terhadap jumlah tenaga kerja yang ada di Indonesia.

\section{SIMPULAN}

Hasil analisis nilai keterkaitan ke depan menunjukkan bahwa sektor pertanian memiliki keterkaitan ke depan secara langsung yang tinggi pada sektor listrik, gas, dan air bersih, sektor pertambangan dan penggalian; sektor keuangan, persewaan, jasa perusahaan; sektor industri pengolahan; sektor perdagangan, hotel, dan restoran; dan sektor pengangkutan dan komunikasi. Ini menunjukkan bahwa pembangunan yang diarahkan kepada pembangunan sektor listrik, gas, dan air bersih, sektor pertambangan dan penggalian; sektor keuangan, persewaan, jasa perusahaan; sektor industri pengolahan; sektor perdagangan, hotel, dan restoran; dan sektor pengangkutan dan komunikasi akan berdampak terhadap pembangunan sektor pertanian. Selanjutnya nilai keterkaitan ke depan tidak langsung menunjukkan bahwa sektor pertanian memiliki keterkaitan ke depan tidak langsung yang tinggi pada sektor industri pengolahan. Secara keseluruhan, nilai keterkaitan ke depan total menunjukkan bahwa sektor pertanian memiliki keterkaitan ke depan yang tinggi pada sektor industri pengolahan dan sektor listrik, gas, dan air bersih.

Hasil analisis nilai keterkaitan ke belakang menunjukkan bahwa sektor pertanian memiliki keterkaiatan ke belakang secara langsung yang tinggi pada sektor listrik, gas, dan air bersih; sektor bangunan; sektor industri pengolahan; sektor pengangkutan dan komunikasi. Selanjutnya nilai keterkaitan ke belakang tidak langsung menunjukkan bahwa sektor pertanian memiliki keterkaitan ke belakang tidak langsung yang tinggi pada sektor listrik, gas, dan air bersih; dan sektor bangunan. Secara keseluruhan, nilai keterkaitan ke belakang total menunjukkan bahwa sektor pertanian memiliki keterkaitan ke belakang yang tinggi 
pada sektor listrik, gas, dan air bersih dan sektor bangunan.

Hasil analisis pengganda output menunjukan bahwa sektor pertanian memiliki dampak pengganda output yang lebih rendah dibandingkan sektor lainnya dalam perekonomian. Untuk hasil pengganda pendapatan rumah tangga dan pengganda kesempatan kerja menunjukkan bahwa sektor pertanian memiliki dampak pengganda yang lebih besar dibandingkan sektor lainnya dalam suatu perekonomian.

Beberapa rekomendasi kebijakan yang dapat disarankan antara lain pemerintah melakukan strategi pembangunan alternatif dengan cara misalnya melalui pengembangan inftrastruktur sarana dan prasarana di pertanian, misalnya dengan cara pembangunan saluran air untuk pengairan yang lebih baik dan menyiapkan lahan untuk meningkatkan hasil output di pertanian. Selain itu pemerintah juga bisa menciptakan pengembangan produk pertanian sehingga dapat menciptakan surplus yang lebih tinggi.

Pemerintah juga diharapkan dapat meningkatkan subsidi pupuk ke sektor pertanian sehingga mendukung peran sektor pertanian dalam penyediaan bahan makanan dalam negeri yang akhirnya dapat memperkecil impor bahan makanan. Di samping itu, pemerintah diharapkan dapat mensejahterakan para petani sehingga para petani mau bekerja di sektor pertanian sehingga dapat menyumbang PDB sektor pertanian. Bagi peneliti selanjutnya hendaknya dapat mengupdate date input output tahun 2015 untuk mendapatkan hasil yang lebih komprehensif.

\section{DAFTAR PUSTAKA}

Arsyad, L. (2010). Ekonomi Pembangunan. Yogyakarta: STIM YKPN.

Astrini, Utari, Retno. (2013). "Analisis Revitalisasi Sektor Pertanian Dalam Pembangunan Terhadap Perekonomian di Jawa Timur Melalui Pendekatan InputOutput". Jurnal Ekonomi Pembangunan, 2(3), 59-174.

Badan Pusat Statistik. (2010). Input-Output. Jakarta.

Badan Pusat Statistik. (2006). Statistika Pertanian. Jakarta.

Badan Pusat Statistik. (2008). Kerangka Teori dan Analisis Tabel Input Output. Jakarta.

Damanik, S. (2011). Analisis Dari Dampak Pengembangan Komoditas Perkebunan Terhadap Perekonomian Wilayah Di Propinsi Sumatera Utara. Diakses dari http://puslitsosekhut.web.id/download. php?page=publikasi\&sub=jurnal\&i2 pada tanggal 14 Desember 2016.

Firmansyah. (2006). Operasi Matrix Dan Analisis Input-Output (I-O) Untuk Ekonomi. Semarang: Universitas Diponegoro.

Hartono, S., dkk. (2015). Peran Sektor Pertanian Terhadap Perekonomian Daerah Istimewa Yogyakarta (Analisis Input-Output Daerah Istimewa Yogyakarta Untuk Komoditas Tebu). Jurnal Social Economic of Agriculture, 4 (1), 1-13.

Irianto, S.G. (2015). Rencana Strategis Direktorat Jenderal Prasarana dan Sarana Pertanian Tahun 2015-2019. Laporan Kementerian Pertanian. Jakarta: Kementerian Pertanian.

Jhingan, M.L. (2007). Ekonomi Pembangunan dan Perencanaan. (Edisi 11). Jakarta: PT Raja Grafindo Persada. 
Kuznets, S.S. (1964). Economic Growth and the Contribution of Agriculture. New York: McGraw-Hill.

Miller \& Blair, P.D. (1985). Input-Output Analysis: Foundations and Extension. New Jearsey: Prentice-Hall, Inc.

Ningtyas, B.R. (2013). Dampak Pembangunan Sektor Pertanian Terhadap Perekonomian Jawa Timur: Studi Kasus Penerapan Model Input Output. Skripsi. Jember: Fakultas Ekonomi.

Perwitasari, H. \& Pinjung, N. (2013). Analisis Input-Output Komoditas Kelapa Sawit di Indonesia. Jurnal Mediagro, 9 (1), 11-21.

Priyarsono \& Sahara. (2006). Ekonomi Regional. Bogor: FEM IPB.

Suhendra, E. (2004). Analisis Struktur Sektor Pertanian Indonesia: Analisis Model Input-Output. Jurnal Ekonomi dan Bisnis, 2 (9), 55-65.

Sukanto, D. (2010). Analisis Peranan Sektor Pertanian Terhadap Perekonomian Jawa
Tengah (Pendekatan Analisis InputOutput). Jurnal Ekonomi dan Bisnis, 1 (2), 13-25.

Suryani, T. (2013). Analisis Peran Sektor Ekonomi Terhadap Pertumbuhan Ekonomi Kabupaten Pemalang (Analisis Tabel Input-Output Kabupaten Pemalang Tahun 2010). Economics Development Analysis Journal, 2(1), 1-9.

Todaro, M.P. (2006). Pembangunan Ekonomi. (Edisi 3). Jakarta: Erlangga.

Utomo, Y.K. (2015). Dampak Investasi Sektor Pertanian Terhadap Perekonomian Provinsi Jawa Timur (Pendekatan Analisis Input Output). Artikel IImiah. Jember: FE UJ.

Widodo, T. (2006). Peran Sektor Informal Terhadap Perekonomian Daerah: Pendekatan Delphi-IO dan Aplikasi. Jurnal Ekonomi dan Bisnis Indonesia, 21(3), 254-26. 